\title{
イヌの実験的歯肉炎におけるコラゲナーゼ活性について
}

第 2 報＼cjkstart炎症発生期間を短縮したときの動態

柳 村 光 寛

新潟大学歯学部歯科保存学第 2 教室

（指導 : 原 耕二 教授）

新潟大学歯学部口腔生化学教室

（指導 : 野原広美 教授）

（昭和 56 年 9 月 20 日受付）

\section{Collagenase Activities in Healthy and Inflamed Gingivae Induced by Plaque in Dogs}

\section{Collagenase and Gelatinase Activities in Dog Gingiva after Short Term Plaque Accumulation}

\section{Mitsuhiro YANAGIMURA}

\author{
Department of Periodontology and Endodontics \\ Niigata University School of Dentistry \\ (Director : Prof. Kohji HARA) \\ Department of Oral Biochemistry \\ Niigata University School of Dentistry \\ (Director : Prof. Hiroyoshi NOHARA)
}

The previous study showed that the collagenase activities in salt extract and two sonicates were significantly higher in inflamed gingiva after 3 weeks of plaque forming period than healthy gingiva in dogs, respectively.

The aim of this study was to extract the collagenase and gelatinase from the healthy and inflamed gingivae after 1 week of plaque forming period and compare their activities with those of 3 week-old gingivitis.

With inflamed gingiva after 1 week of plaque forming period, two forms of collagenase, the soluble enzyme free its substrate and insoluble enzyme bound to the substrate, were extracted according to the methods as described previously. Collagenase activ-

本論文の要旨は昭和 56 年 5 月第 24 回春季日本歯周病学会総 会において発表した。 ity was measured using $\left[{ }^{14} \mathrm{C}\right]$-acetylated collagen with high specific activity in solution as substrate and separating the reaction products by $50 \%$ dioxane. Treatment with a high concentration of trypsin was also necessary for detection of collagenase activities in all the extracts as in the case of experimentally induced 3 week-old gingivitis.

The collagenase activities in salt extract and the first sonicate were significantly higher in inflamed gingiva after 1 week of plaque forming period than in healthy gingiva respectively, but that of the second sonicate showed no significant increase. Furthermore, the rates of the increase in two fractions were smaller than those in 3 week-old gingivitis.

From these results, it is suggested that both soluble and insoluble forms of collagenase in dog start to increase within 1 week after the induction of inflam- 
mation and continue the increase for at least 2 weeks. On the other hand, gelatinase activity did not vary significantly by the induction of inflammation.

\section{緒論}

生理的条件下で未変性コラーゲンモノマーに作用し て, 3/4 と $1 / 4$ の 2 つの fragment $\left(\mathrm{TC}_{\mathrm{A}}, \mathrm{TC}_{\mathrm{B}}\right)$ に分解す るコラゲナーゼは, 結合組織の破壊を惹起する主因であ ると考えられている( ${ }^{1 \sim 5}$ 。現在までのところ, 歯肉 中の コラゲナーゼ活性に関する研究報告としては, 組織培養 によるものが多い(6 9)。しかしながら，より in vivo の 状態を反映する形でコラゲナーゼを歯肉から直接抽出 し，その活性を検討した報告はきわめて少ない10)。

著者は，さきにイヌに実験的歯肉炎を惹起させた歯肉 中のコラゲナーゼ活性を測定し, 健康歯肉のそれと比較 検討を行なった ${ }^{11)}$ 。その結果, 歯肉中には塩可溶性の遊 離型 (free type) と, 超音波処理や高濃度の塩溶液での 超音波処理により抽出される結合型 (bound type) のコ ラゲナーゼの両者が, 大部分潜在型 (latent form) とし て抽出されること, しかもこれらコラゲナーゼの活性 は, 健康歯肉に比較して炎症歯肉の方が有意に上昇して いることを認めた。

本研究の目的は, プラーク蓄積による炎症発生期間を 1 週間にした場合のコラゲナーゼ活性の動態を知ること である。即ち, この炎症発生期間での遊離型及び結合型 コラゲナーゼの活性の変化を追求した。なおゲラチナー ゼの活性についても検討したので併せて報告する。

\section{研究材料及び方法}

\section{I. 材 料}

トリプシン及びトリプシンインヒビターは Sigma 社 製を, $\left[1-{ }^{14} \mathrm{C}\right]$ acetic anhydride は The Radiochemical Centre, Amersham, England 製を使用した。

\section{II. イヌの実験的歯肉炎の発生方法について}

実験には体重 $10 \mathrm{~kg}$ 前後の雑種成犬 4 頭( 22 頭, 우 2 頭）を使用した。実験部位ならびに実験開始までの操作 については，著者が前に報告した通りである11)。ただし ブラッシングにより健康歯肉を確立させる期間は 5 週間 とし, ブラッシング開始時から 2 週間 は $0.2 \%$ chlorhexidine を口腔内にブラッシング終了後噴霧させ, ブラ
ッシングの効果を促進させた ${ }^{12)}$ 。その後 3 週間はブラッ シングのみを続け, 臨床的健康歯肉を確立した。

実験側には歯頸部に浅い溝を形成し, 絹糸を結禁し た。飼料は従来の固型飼料（日本クレア社製）を軟泥状 にしたものを与えて炎症を発生させ 1 週間後にブラッシ ングを続けた健康歯肉と同時に歯肉を剝離切除した。

\section{III. 歯肉抽出液の調整法について}

著者の報告した方法 ${ }^{11)}$ に準じて行なった。

IV. コラゲナーゼ活性の測定について

1) ${ }^{14} \mathrm{C}$ 標識コラーゲンの調整

2）反応溶液の組成

1）及び 2) は，それぞれ Gisslow ら ${ }^{13)}$, Terato ら ${ }^{14)}$ の方法に準じて行なった。

3）トリプシンによる歯肉抽出液の前処理

3）は，著者の報告した方法 ${ }^{11)}$ に準じて行なった。

\section{V. 歯肉抽出液中のゲラチナーゼの活性測定について} Harris ら ${ }^{15)}$ の方法に準じて行なった。

\section{VI. 組織学的考察のための標本作製について}

実験側, 対照側の上下 $\mathrm{P}_{2}$ (6 番) の煩側歯肉中央部か ら組織片を採取し, 通法に従ってヘマトキシリン・エオ ジン染色を行ない, 組織学的観察を行なった。

\section{VII.タンパク質の定量}

タンパク質の定量は, Lowry ら ${ }^{16)}$ の方法に従って測定 した。

\section{結果}

\section{1. 臨床的健康歯肉の確立について}

実験に使用した成犬 4 頭は，いずれも永久歯のすべて 萌出したものであるが生齢が不明でその生育環境も個体 間で異なるものであった。歯肉の状態は発赤, 腫脹がい ずれのイヌにも中等度以上認められ，特に上顎の白歯の 歯面には歯石の沈着が多量に観察されるものが大部分で あった。そのため徹底したスケーリングと研磨を行なっ た後, ブラッシング開始時から 2 週間は $0.2 \%$ chlor- 
Table 1 Wet weight of resected gingiva and protein content in each fraction

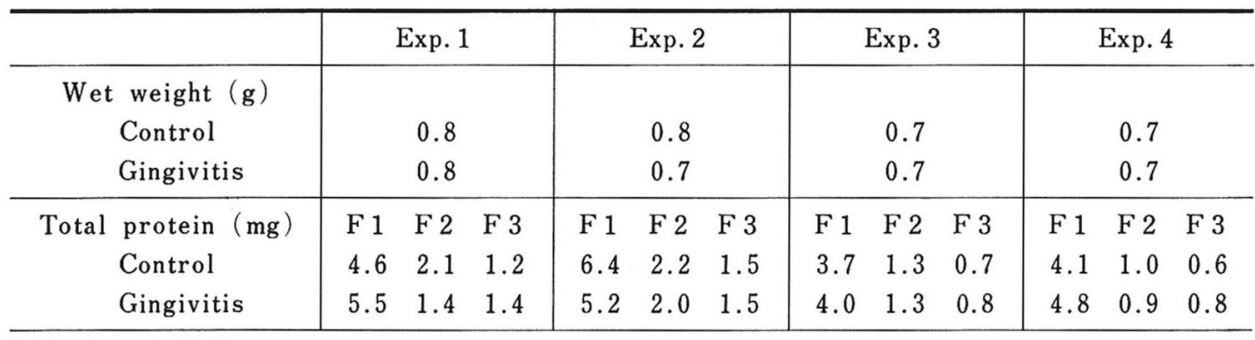

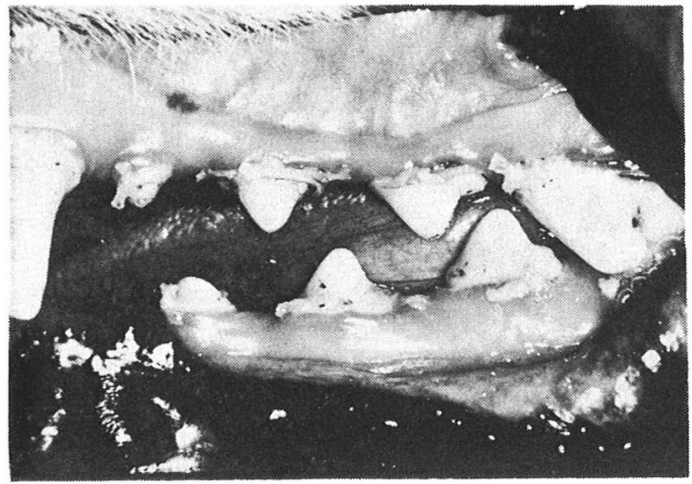

Fig. 1 Establishment of gingivitis in the experimental side one week after the experi. ment

hexidine の口腔内噴霧をブラッシング直後に行ない, 機械的清掃に加えて化学的なプラーク形成の抑制作用を 期待した。その結果, 臨床的健康歯肉の確立に, 既報の ごとくブラッシングのみで 7-12 週間を要したのに対し, 本研究では 5 週間に短縮できた。

\section{2. 実験的歯肉炎の発生について}

ブラッシング期閒中は，できるだけブラーク形成を促 進させないように固型飼料を与えたが，プラーク蓄積期 間中は固型飼料に熱湯を加えて軟泥状にしたものを与. え, 1 週間プラークを蓄積させた。その結果, 結紧歯の 歯頸部には肉眼でも判別できる程度のプラークの形成が 観察された (Fig. 1)。

歯肉炎の状態は軽度の発赤と腫脹が認められ，歯肉溝 上皮を軽く擦過するするだけで出血する傾向が観察され た。これらの変化は辺縁歯肉に限局して観察されるもの が大部分で， 3 週間の炎症発生期間の場合のように付着 歯肉にまで炎症が及んだ所見は認められなかった。

一方,ブラッシングを継続した対照側では実験期間 中, 臨床的健康歯肉を維持することができた。
3. コラゲナーゼ抽出に使用した歯肉の湿重量と各フ ラクションに於けるタンパク濃度について

コラゲナーゼの抽出に使用した歯肉の湿重量, 抽出後 の各フラクションに於ける総タンパク量は, Table 1 に 示寸通りである。各個体の剝離切除後の歯肉の湿重量 は，対照側と実験側でほぼ一致している。

抽出後の総タンパク量に個体差が生じたのは，抽出操 作によるものか，歯肉の状態の違いによるものか明らか でないが，前に報告した通り，最初の乳鉢乳棒による均 一化に若干の差異が生じたことに起因することも考えら れる。

4. 歯肉抽出液中の各フラクションに於けるコラゲナ 一ゼの活性について

Table 2 は, 炎症発生後 1 週間の歯肉とブラッシング を継続した健康歯肉の, トリプシン処理後のコラゲナー ゼ活性の結果である。上段が湿重量当りの活性値, 下段 が酵素タンパク $(\mathrm{mg})$ 当りの活性值を示す。湿重量当り のコラゲナーゼ活性は, 中性塩可溶分画 (F1), 超音波 処理分画 (F2) に於ていずれも実駼側が健康側よりも有 意に上昇していた。そして F1 と F2 の活性の上昇率 は，それぞれ約 $80 \%$ ，約 $50 \%$ でありこれら上昇率は， 3 週間群の約 $200 \%$ (F1) 約 100\% (F2) に比較して少 なかった。これは対照側としての健康歯肉の活性が，3 週間群のそれと比較した場合，一般に高いことによるも のである（Fig. 2，3）。しかしこのことがいかなる原因 によるものであるかは不明である。高塩濃度下での超音 波処理分画 (F3) では，炎症によるコラゲナーゼ活性の 上昇は認められなかった。

一方, 酵素タンパク (mg) 当りの活性, 即ち比活性 についてみると F1, F2 とも実験側が対照側に比較して 有意に増加していることが認められ， 3 週間群と同じ傾 向を示した (Table 3)。

各フラクション間での湿重量当りの活性は，対照側及 
Table 2 Collagenase activities in healthy and inflamed gingivae after one week of plaque forming period

\begin{tabular}{|c|c|c|c|c|c|c|}
\hline \multirow[b]{2}{*}{ Fraction } & \multicolumn{3}{|c|}{ Control } & \multicolumn{3}{|c|}{$\begin{array}{l}\text { Gingivitis after one week of } \\
\text { plaque forming period }\end{array}$} \\
\hline & $F_{1}$ & F 2 & F 3 & F 1 & F 2 & F 3 \\
\hline \multicolumn{7}{|c|}{$\left[{ }^{14} \mathrm{C}\right]$-radioactivity released $\left(\mathrm{dpm} \times 10^{-3} / \mathrm{g}\right.$ wet weight of tissue $)$} \\
\hline Exp. 1 & 113.2 & 56.0 & 48.5 & 270.5 & 80.2 & 56.7 \\
\hline Exp. 2 & 110.4 & 98.2 & 76.5 & 184.6 & 122.5 & 97.7 \\
\hline Exp. 3 & 153.0 & 42.7 & 21.3 & 246.9 & 86.3 & 48.6 \\
\hline Exp. 4 & 189.6 & 62.2 & 13.0 & 347.4 & 102.5 & 64.9 \\
\hline Mean \pm S.D. & $\stackrel{* *}{141.6 \pm 37.4}$ & $\begin{array}{l}* \\
64.8 \pm 23.7\end{array}$ & $\begin{array}{l}\text { N.S. } \\
39.8 \pm 28.7\end{array}$ & $\begin{array}{l}* * \\
262.3 \pm 67.2\end{array}$ & $\begin{array}{l}* \\
97.9 \pm 18.9\end{array}$ & $\begin{array}{l}\text { N.S. } \\
67.0 \pm 21.5\end{array}$ \\
\hline \multicolumn{7}{|c|}{$\left[{ }^{14} \mathrm{C}\right]$-radioactivity released $\left(\mathrm{dpm} \times 10^{-3} / \mathrm{mg}\right.$ enzyme protein $)$} \\
\hline Exp. 1 & 19.6 & 21.3 & 32.3 & 39.5 & 45.8 & 32.4 \\
\hline Exp. 2 & 13.8 & 35.7 & 40.8 & 24.8 & 42.8 & 45.6 \\
\hline Exp. 3 & 28.6 & 22.9 & 21.3 & 43.2 & 46.5 & 42.5 \\
\hline Exp. 4 & 32.2 & 43.5 & 15.1 & 50.6 & 79.7 & 56.7 \\
\hline Mean \pm S.D. & * $23.6 \pm 8.4$ & $\begin{array}{l}* * * \\
30.8 \pm 10.6\end{array}$ & $\begin{array}{l}\text { N.S. } \\
27.3 \pm 11.4\end{array}$ & $\stackrel{*}{39.5 \pm 10.8}$ & $\begin{array}{l}* * * \\
53.7 \pm 17.4\end{array}$ & $\begin{array}{l}\text { N.S. } \\
44.3 \pm 10.0\end{array}$ \\
\hline
\end{tabular}

F 1 : extract with buffer $A$

F 2 : extract by sonication in buffer A

F 3 : extract by sonication in buffer $B$

Buffer A : $0.03 \mathrm{M}$ Tris- $\mathrm{HCl} 0.2 \mathrm{M} \mathrm{NaCl} 0.05 \mathrm{M} \mathrm{CaCl}_{2}(\mathrm{pH} 7.5)$

Buffer B : $0.03 \mathrm{M}$ Tris $-\mathrm{HCl} 1.0 \mathrm{M} \mathrm{NaCl} 0.05 \mathrm{M} \mathrm{CaCl}_{2}(\mathrm{pH} 7.5)$

$*$ : significant at $\mathrm{p}<0.01 \quad * *$ : significant at $\mathrm{p}<0.02$

***: significant at $\mathrm{p}<0.05$ N.S. : not significant at $\mathrm{p}>0.05$

Table 3 Collagenase activities in healthy and inflamed gingivae after three weeks of plaque forming period

\begin{tabular}{|c|c|c|c|c|c|c|}
\hline \multirow[b]{2}{*}{ Fraction } & \multicolumn{3}{|c|}{ Control } & \multicolumn{3}{|c|}{$\begin{array}{l}\text { Gingivitis after three weeks of } \\
\text { plaque forming period }\end{array}$} \\
\hline & $F_{1}$ & $\mathrm{~F} 2$ & F 3 & F 1 & $\mathrm{~F} 2$ & F 3 \\
\hline \multicolumn{7}{|c|}{$\left[{ }^{1 .} \mathrm{C}\right]$-radioactivity released $\left(\mathrm{dpm} \times 10^{-3} / \mathrm{mg}\right.$ enzyme protein $)$} \\
\hline Exp. 1 & 8.3 & 16.4 & 11.8 & 32.9 & 32.5 & 28.6 \\
\hline Exp. 2 & 19.8 & 23.9 & 15.7 & 35.1 & 34.3 & 25.5 \\
\hline Exp. 3 & 12.6 & 10.6 & 17.6 & 38.5 & 36.5 & 28.9 \\
\hline Exp. 4 & 9.2 & 16.3 & 28.4 & 29.0 & 34.5 & 20.8 \\
\hline Mean \pm S.D. & $\begin{array}{l}* \\
12.4 \pm 5.2\end{array}$ & $\begin{array}{l}* * \\
16.8 \pm 5.4\end{array}$ & $\begin{array}{l}\text { N.S. } \\
18.0 \pm 7.1\end{array}$ & * $33.8 \pm 3.9$ & ** $34.4 \pm 1.6$ & $\begin{array}{l}\text { N.S. } \\
25.9 \pm 3.7\end{array}$ \\
\hline
\end{tabular}

*: significant at $\mathrm{p}<0.005 * *$ : significant at $\mathrm{p}<0.02 \quad$ N.S. : not significant at $\mathrm{p}>0.05$

び実験側とも 3 週間群と同様 F1が最も高い活性を示し, 次いで F2, F3 の順であった。

一方，比活性は対照側及び実験側とも 3 つのフラクシ ヨン間で有意の差は認められなかった。
このように 1 週間という短期間の炎症発生後, すでに 遊離型のコラゲナーゼである F1 の活性と, 結合型のコ ラゲナーゼの一部である F2 において，著明に活性が上 昇していることが示された。 


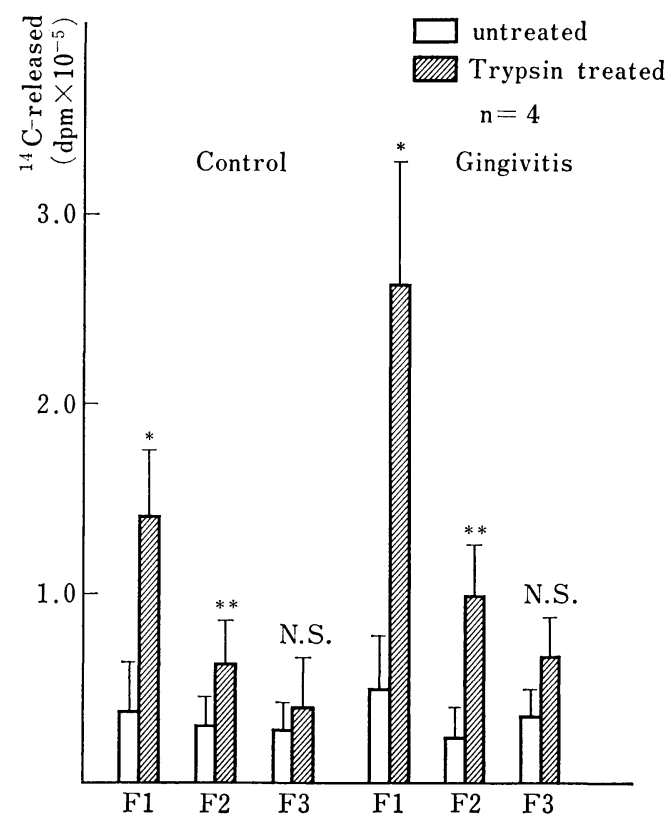

Fig. 2 Collagenase activities of gingival extracts after one week of plaque forming period (dpm/g tissue)

F1, F 2, F3. : see Table 2

* : significant at $\mathrm{p}<0.02$

** : significant at $\mathrm{p}<0.01$

N.S. : not significant at $\mathrm{p}>0.05$

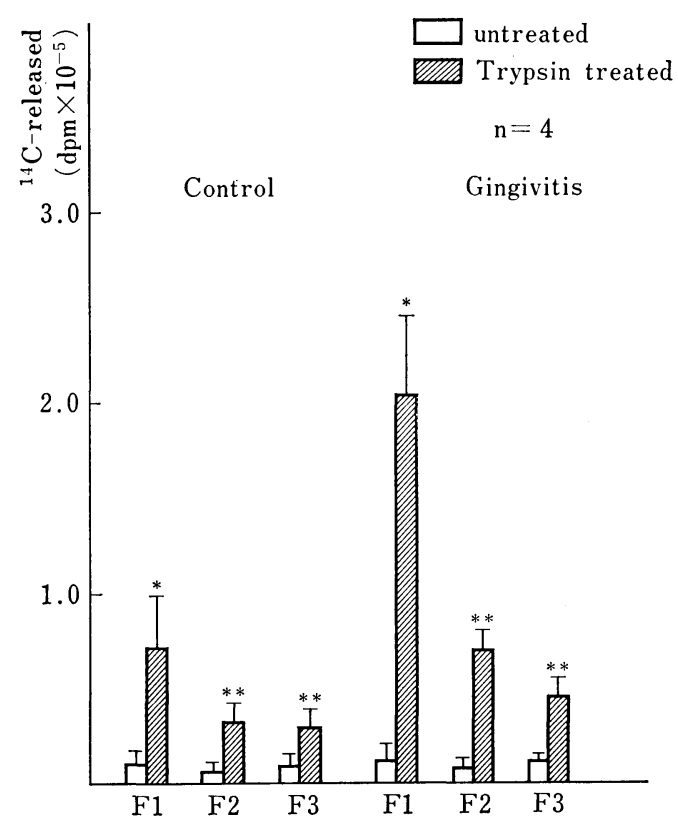

Fig. 3 Collagenase activities of gingival extracts after three weeks of plaque forming period (dpm/g tissue)

F 1, F 2, F 3. : see Table 2

$*$ : significant at $\mathrm{p}<0.02$

$* *$ : significant at $\mathrm{p}<0.05$

Table 4 Gelatinase activities of gingival extracts

\begin{tabular}{ccc|ccc}
\hline Control & \multicolumn{3}{c}{} & \multicolumn{3}{c}{$\left(10^{-3} \mathrm{dpm} / \mathrm{g}\right.$ tissue $)$} \\
\hline untreated & $\begin{array}{c}\text { Trypsin } \\
\text { treated }\end{array}$ & Gingivitis & & untreated & $\begin{array}{c}\text { Trypsin } \\
\text { treated }\end{array}$ \\
\hline Exp. 1 & 41.0 & 178.0 & Exp. 1 & 33.7 & 211.0 \\
Exp. 2 & 38.1 & 147.4 & Exp. 2 & 40.4 & 174.2 \\
Exp. 3 & 50.7 & 191.0 & Exp. 3 & 39.0 & 160.0 \\
Exp. 4 & 36.8 & 106.3 & Exp. 4 & 71.0 & 187.0 \\
\hline & N.S. & N.S. & & N.S. & N.S. \\
Mean \pm S.D. & $41.7 \pm 5.4$ & $155.7 \pm 37.6$ & Mean \pm S.D. & 46.6 \pm 16.8 & $183.1 \pm 21.6$ \\
\hline
\end{tabular}

N.S. : not significant at $\mathrm{p}>0.05$

5. 歯肉抽出液中のグラチナーゼ活性について

歯肉抽出液の中性塩可溶分画について, そのゲラチナ 一ゼ活性を測定して実験側と対照側で比較した（Table 4)。ゲラチナーゼはコラゲナーゼと同様, トリプシ ンで前処理するとその活性の著明な上昇が認められた
が， 3 週間群の結果と同様, 実験側と対照側間で有意な 差は認められなかった。

\section{6. 対照側及び実験側の組織学的所見について}

Fig. 4 は実験側の歯肉の組織標本の一例である。1 週 


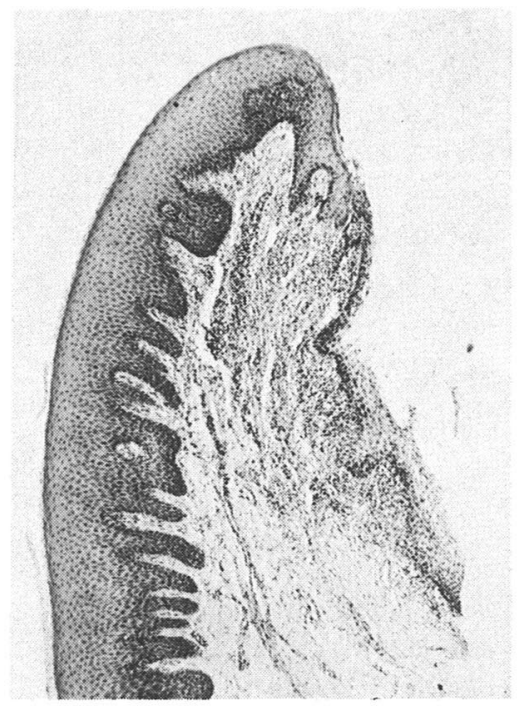

Fig. 4 Histologic inflamed specimen from the buccal area of the second premolar one week after the ligature original magnification $\times 20, \mathrm{H}-\mathrm{E}$ staining

間のプラーク蓄積期間後の歯肉では, 炎症性細胞は歯肉 固有層にび漫性に広がっており，また歯肉線維の発達は 悪く中等度の消失をきたしているのが見られる。しかし 3 週間群の炎症歯肉に見られたような, 高度の歯肉線維 の消失や肉芽の形成等は見られなかった。一方，上皮付 着部には強い炎症性細胞の浸潤がみられ，その広がりは さらに深部へ拡大している。さらに上皮細胞間の結合は 細胞間隙の拡張を生じ，上皮は側方へ突起状肥厚増殖し ている。

対照側の歯肉には，炎症性細胞の浸潤はまったく見ら れず正常像を示していた。

\section{考察}

歯周病に於ける歯肉コラーゲンの酵素的分解過程は, 他の組織でもみられるようにコラグナーゼによる特異的 なコラーゲン分子の切断と, その後のプロテアーゼによ る消化の段階を経るという可能性がまず考えられる。

著者は, 初期歯肉炎に於けるこれらコラーゲンの分解 過程に着目し，歯周病の病因を考える上でイヌに発生さ せた実験的歯肉炎の歯肉, 対照としてブラッシングを続 け維持した健康歯肉から直接，いくつかの段階に分けて コラゲナーゼを抽出し比較検討した ${ }^{11)}$ 。その結果, 3 週 閒の炎症発生後の歯肉からは遊離型及び結合型のコラゲ
ナーゼが潜在型 (latent form) として大部分が抽出さ れ，トリプシン処理で活性化されることが認められた。

本研究で著者は, 初期歯肉炎に於けるコラーゲンの分 解に関与するコラゲナーゼの作用を検討すべく, 炎症発 生期間を 1 週閒に短縮したときの炎症歯肉及び健康歯肉 を得た後, 各抽出分画のコラグナーゼの活性の動態を検 討した。またゲラチナーゼも抽出してその活性の動態に ついて検討した。

実験的歯肉炎は，徹底したブラッシングにて健康歯肉 を確立した後, 歯頸部に溝を形成し絹系を結禁しプラー クの蓄積を促進させ発生させた。その結果, プラークは 1 週間という短期間にもかかわらず，歯頸部の歯肉辺縁 部を中心に多量に蓄積していた。このことは，歯頸部に 結係した絹系が形成されたプラークを蓄積させるのに効 果的であることを示唆するものである。

歯肉から直接抽出されるコラゲナーゼの活性を検討す るためには，高感度の測定法によら斌ばならない。とい らのも, イヌに於て, $\frac{\mathrm{I}_{3}-\mathrm{P}_{4}}{\mathrm{I}_{3}-\mathrm{M}_{1}}$ の左右の片側の唇煩側歯 肉を，付着歯肉及び歯間乳頭を含めて全部剝離しても， 湿重量 $1 \mathrm{~g}$ 前後のサンプルしか得られぬからである。こ のため著者は, Terato ら ${ }^{14)}$ らの方法を $1 / 4$ に scale down し, かつ Gisslow ら ${ }^{15)}$ の方法でアセチル化した比放射 活性の高いコラーゲン $\left(1.25 \times 10^{6} \mathrm{dpm} / \mathrm{mg}\right)$ を基質と して使用した。このような改良を加えることによって $\mu \mathrm{g}$ 単位のコラーゲンの分解が $0.1 \mathrm{~m} l$ の反応系で測定 可能になった。アセチル化コラーゲンは, 最近コラゲナ 一ゼの活性の測定に利用されつつある ${ }^{17,18)}$ 。

すでに報告したように, イヌの歯肉抽出液のアセチル 化コラーゲンに対する反応生成物の SDS ポリアクリル アミドダル電気泳動による分析の結果, コラーダンの分 解は typical な動物性コラゲナーゼの作用によるもの で, コラーダンモノマーの $3 / 4$ と $1 / 4$ の断片 $\left(\mathrm{TC}_{\mathrm{A}}, \mathrm{TC}_{\mathrm{B}}\right)$ が生じていた。さらに反応生成物を示すバンドがゲル上 の放射能の分布に一致することも示され，そのカウント の殆どがグルを溶解して得たカウントの総和に一致する ことも確認した。

コラゲナーゼは, 歯肉組織中では 2 つの型で存在する ことが知られている。即ち, 遊離型と結合型である。著 者も歯肉から 2 つの型のコラゲナーゼを 3 つの段階に分 けて抽出した結果, かなりの量の結合型のコラゲナーゼ が, すでに遊離型のコラゲナーゼを抽出した後の沈渣に 存在することが認められた。しかし latent form で抽出 されるため, トリプシン処理後の活性を測定し比較検討 した。トリプシンによる活性化は, Uitto ら ${ }^{10)}$ が歯肉ホ 
モジネートからセファデックス G-100 によるゲル濾過 後活性を検出した方法に比較すると迅速で，かつ，より 少量のサンプルに応用できる利点がある。

本研究の結果, 歯肉コラゲナーゼの活性は, 中性塩可 溶分画 (F1) と超音波処理分画 (F2) のいずれも, 湿重 量当り及び酵素タンパク（mg）当りで, 実験側が対照 側より有意に上昇していた。しかし, 高塩濃度下での超 音波処理分画 (F3) では，湿重量当り及び酵素タンパク (mg) 当りの活性には, 実験側と対照側間で有意な差は 認められなかった。 1 週間という比較的短期間のプラー ク蓄積にもかかわらず，このように遊離型の酵素 F1 と 結合型の酵素の一部である F2 に活性の上昇が認められ たことは, プラークの蓄積により発生した歯肉炎に伴っ てコラゲナーゼの活性も上昇していることが示唆され る。そしてこの活性の上昇は， 3 週間後にも著明に認め られることから, 活性上昇は 1 週閒内に起こりさらに 2 週間は持続していることになる。

また結合型のコラゲナーゼの活性については, 1 週間 群では F2 で 3 週間群では F2 と F3 で活性の上昇が認 められることからみても, 歯肉では炎症の初期からコラ ゲナーゼによるコラーゲンの分解が関与しており，この ことが初期歯肉炎に於ける歯肉コラーゲンの破壊因子の 一つとして成立している可能性が考えられる。

歯周病の臨床的所見とコラゲナーゼの活性の比較研究 は大部分, 組織培養によるコラゲナーゼの活性の測定に 依存している ${ }^{699}$ 。最近, Geiger $ら^{9)}$ 仗健康歯肉及び各 病期の歯肉即ち, 中等度及び高度の歯肉炎由来の歯肉を 培養してコラゲナーゼの活性の比較を行なったところ, 健康歯肉では培養期間中コラゲナーゼの活性は低く一定 していたのに対し，歯肉炎歯肉では培養期間の経過とと もに活性が上昇し健康歯肉に対して高度の炎症歯肉では 3-5 倍, 中等度の炎症歯肉では 2 倍も活性が高かったと 報告している。しかし組織培養で得られるコラゲナーゼ の活性が in vivo の活性を正しく反映するのかについて は問題がある。

コラゲナーゼ産生細胞は, in vitro で種々の細胞につ いて同定されている。歯肉についても螢光抗体法を用い て，その局在を明らかにしようとする試みも報告されて いる19)。それによると，初期治療を受けた患者から得た 歯肉や臨床的に炎症の徴候の認められぬ歯肉では, コラ ゲナーゼの存在は証明されなかった。しかし慢性炎症の ある歯肉では，コラゲナーゼはポケット上皮に近い結合 組織を中心に観察された。そして多数の炎症性細胞の浸 潤を伴っているが，その中からコラゲナーゼ産生細胞を
同定することはできなかったと述べている。

現在のところ in vivo でのコラゲナーゼの産生細胞の 同定は困難であるが今後の研究が待たれる。

ゲラチナーゼに関しては中性塩可溶分画についてのみ 検討したが，殆どが潜在型 (latent form) として存在し トリプシン処理で著明な活性の上昇が認められた。しか しこの上昇は実験側のみならず対照側でも認められ, 両 者間に有意な差は認められなかった。このことから，ゲ ラチナーゼは歯肉炎に於て重要な役割を果している可能 性は少ないものと考えられる。

\section{結論}

イヌの実験的歯肉炎に於けるコラゲナーゼ及びゲラチ ナーゼの活性をプラーク蓄積 1 週間後の炎症歯肉とブラ ッシングを続けて維持した健康歯肉について比較し以下 の結論を得た。

1） 1 週間の炎症発生期間の歯肉では, 健康歯肉に対 して, すでにコラゲナーゼの活性が上昇していることが 示唆された。

2） 1 週間の炎症発生期間で, 結合型のコラゲナーゼ である F2 の活性の上昇が認められたことから，この時 期で歯肉コラーゲンの分解が開始していることが考えら れる。

3）ゲラチナーゼについては, その殆どが latent form で存在し， 1 週間の炎症発生期間でも 3 週間群と同様， 健康歯肉と炎症歯肉との間にその活性に有意な差は認め られなかった。

謝辞 : 稿を終えるにあたり，終始懇篤なる御指導と御校閲を 賜りました原 耕二教授, 野原広美教授に心から感謝申し上げ ます。また本研究の遂行に際し御援助及び御協力いただきまし た本学口腔生化学教室の諸先生方ならびに保存学第 2 教室員の 皆様に深謝いたします。

\section{文献}

1) Harris, E.D.Jr. and Cartwright, E.C. : Mammalian collagenases; in Proteins in mammalian cells and tissues, ed. Barrett, A. J., NorthHolland Biochemical Press, Amsterdam, 1977, 249-283.

2) Woessner, J.F.Jr. : Mammalian collagenases. Clin. Orthop., 96 : 310-326, 1973. 
3) Harris, E.D.Jr. and Krane, S.M. : Medical progress : Collagenases, Part I, II, III. N. Engl. J. Med., 291 : 557-563, 605-609, 652-661, 1974.

4) Weiss, J.B. : Enzymic degradation of collagen; in International review of connective research, ed. Hall, D.A. and Jackson, D.S., Vol. 7, Academic Press, New York and London, 1976, 101157.

5) Gross, J. : Aspects of the collagenase; in Biochemistry of collagen, ed. Ramachandran, G.N. and Reddi, A.H., Plenum Press, New York and London, 1976, 275-318.

6) Beutner, E.H., Triftshauser, C. and Hazen, S. P. : Collagenase activity of gingival tissue from patients with periodontal disease. Proc. Soc. Exp. Biol. Med., 121 : 1082-1085, 1966.

7) Bennick, A. and Hunt, A.M. : Collagenolytic activity in oral tissues. Archs. Oral Biol., 12 : 1-9, 1967.

8) Fullmer, H.M., Gibson, W.A., Lazarus, G.S., Bladen, H.A. and Wheden, K.A. : The origin of collagenase in periodontal tissues of man. J. Dent. Res., 48 : 646-651, 1969.

9) Geiger, S. and Harper, E. : Human gingival collagenase in periodontal disease: The release of collagenase and the breakdown of endogeneous collagen in gingival explants. J. Dent. Res., 59 : 11-16, 1980.

10) Uitto, V.-J., Turto, H. and Saxén, L. : Extraction of collagenase from human gingiva. J. Periodont. Res., 13 : 207-214, 1978.

11）柳村光寛：イヌの実験的歯肉炎におけるコラゲナ 一ゼ活性について. 日歯周誌, $22: 575-591$,
1980.

12) Hamp, S.-E., Lindhe, J. and Löe, H. : Long term effect of chlorhexidine on developing gingivitis in the beagle dog. J. Periodont. Res., $8: 63-70,1973$.

13) Gisslow, M.T. and McBride, B.C. : A rapid sensitive collagenase assay. Anal. Biochem., $68: 70-78,1975$.

14) Terato, K., Nagai, Y., Kawanishi, K. and Yamamoto, S. : A rapid assay method of collagenase activity using ${ }^{14} \mathrm{C}$-labeled soluble collagen as substrate. Biochim. Biophys. Acta, 445 : 753762, 1976.

15) Harris, E.D.Jr. and Krane, S.M. : An endopeptidase from rheumatoid synovial tissue culture. Biochim. Biophys. Acta, 258 : 566576, 1972.

16) Lowry, O.H., Rosebrough, N.J., Farr, A.L. and Randall, R.J. : Protein measurement with the folin phenol reagent. J. Biol. Chem., 193 : 265275, 1951.

17) Sellers, A., Murphy, G., Meikle, M.C. and Reynolds, J.J. : Rabbit bone collagenase inhibitor blocks the activity of other neutral metalloproteinases. Biochem. Biophys. Res. Commun., 87 : 581-587, 1979.

18) Cawston, T.E. and Tyler, J.A. : Purification of pig synovial collagenase to high specific activity. Biochem. J., 183 : 647-656, 1979.

19) Wooley, D.E. and Davies, R.M. : Immunolocalization of collagenase in periodontal disease. J. Periodont. Res., 16 : 292-297, 1981. 